\title{
A meta-analysis on STEM studies in early childhood education
}

\author{
Seçil Yücelyiğit ${ }^{(1 D}$ \\ TED University, Education Faculty, Department of Elementary Education, Early Childhood Education Ankara, \\ Turkey, secil.yucelyigit@tedu.edu.tr \\ Zerrin Toker ${ }^{(D)}$ \\ TED University, Education Faculty, Department of Mathematics and Science Education, Ankara, Turkey, \\ zerrin.toker@tedu.edu.tr
}

\begin{abstract}
The increasing number of studies on the STEM approach necessitates a holistic and comparative evaluation of the results. This study aims to investigate and evaluate the cumulative results of the experimental studies used STEM approach for preschool children. In this study, the meta-analysis method was used. Despite a great number of studies about STEM education, only a limited number of studies were accessed by the keywords "preschool", "early childhood" and "experimental study". The effect size obtained (0.556) is at a level that can be considered as moderate according to the classification used in meta-analysis studies. STEM studies aimed at preschool children have positive effects on children's learning and development. However, more experimental studies on STEM in the preschool field are needed. It can be suggested that preschool teachers can be encouraged to design and implement STEM practices in their class. For further research, the results of the meta-analysis can be supported by content analysis, and a similar study can be conducted for the other grade levels.
\end{abstract}

Keywords: $\quad$ Early childhood, Meta-analysis, Preschool, STEM education, STEM practice

\section{Erken çocukluk eğitimi STEM çalışmaları üzerine bir meta-analiz araştırmas1}

ÖZ STEM yaklaşımı ile ilgili artan sayıda çalışma, sonuçların bütüncül ve karşılaştırmalı olarak değerlendirilmesini gerektirmektedir. Bu çalışma, okul öncesi dönemde STEM yaklaşımının kullanıldığı deneysel çalışmaların kümülatif sonuçlarını araştırmayı ve değerlendirmeyi amaçlamaktadır. Çalışmada meta-analiz yöntemi kullanılmıştır. STEM eğitimi ile ilgili çok sayıda çalışmaya rağmen, "okul öncesi”, "erken çocukluk" ve "deneysel çalışma" anahtar sözcükleriyle sınırlı sayıda çalışmaya erişilmiştir. Elde edilen etki büyüklüğü $(0,556)$, meta-analiz çalışmalarında kullanılan sınıflandırmaya göre orta dereceli kabul edilebilecek düzeydedir. Sonuçlar STEM çalışmalarının çocukların öğrenmesi ve gelişimi üzerinde olumlu etkileri bulunduğunu, bununla birlikte, okul öncesi alanında STEM ile ilgili daha fazla deneysel çalışmaya ihtiyaç olduğunu göstermektedir. Okul öncesi öğretmenlerinin sınıflarında STEM uygulamaları tasarlamaları ve uygulamaları için teşvik edilebileceği önerilebilir. Daha fazla araştırma için, meta-analizin sonuçları içerik analizi ile desteklenebilir ve diğer sınıf seviyeleri için benzer bir çalışma yapılabilir.

Anahtar

Sözcükler: $\quad$ Erken çocukluk, Meta-analiz, Okul öncesi, STEM eğitimi, STEM uygulamaları

Citation: $\quad$ Yücelyiğit, S. \& Toker, Z., (2021). A meta-analysis on STEM studies in early childhood education. Turkish Journal of Education, 10(1), 23-36. DOI: 10.19128/turje.783724 


\section{INTRODUCTION}

Implementations of STEM studies are encountered in different educational areas and at different levels of education starting from early childhood period. One of the main aims of preschool education is to acquire the skills that children will use throughout their lives (Aral, Baran, Bulut, \& Çimen, 2000; Gropen, Clark-Chiarelli, Hoisington, \& Ehrlich, 2011). During the preschool period, children do not yet have the competence in reading and writing but they are experts of observation, investigation, exploration, questioning, drawing, and designing (Katz, 2010; Tuğrul, 2002) These skills at the same time form the basis for STEM education. STEM (Science-Mathematics-Engineering-Technology) education is regarded as an integrated approach that assembles science, mathematics and engineering skills benefiting from technology with the goal of developing products that can be used in daily life problems (Akgündüz et.al., 2015; Aşık, Doğança Küçük, Helvacı, \& Çorlu, 2017). The similarities and common points underlying these two educations reveal the necessity of evaluating STEM education from early childhood perspective.

Children like to observe how ants march and carry food, they perpetually ask questions such as why the leaves change color in autumn, what makes the sky blue and etc., they keep trying to build bridges with blocks even if they fail on first attempt, they present sense of number when asked to choose between more and less candies even if they do not know how to count (Aldemir \& Kermani, 2017; Moomaw, 2013). These innate skills that children possess by birth, lay the foundations of early childhood education and correspond to the skills that STEM education aims to qualify systematically. In this regard STEM approach is found to be feasible and suitable in early childhood education. Thus, STEM practices can be used as a powerful way to relate these experiences to learning and STEM education can be considered as an important tool in developing the basic skills of preschool children.

A search with the keywords 'early childhood' and 'STEM education' results with a long list of studies with four digits representing the thousands. These studies, which are increasing day by day, are pleasing in terms of STEM research. In line with this, the huge number of STEM studies is considered promising due to its potential to encourage quality work. The findings of the researches reveal that a qualified STEM activity which meets the requirements of STEM education has an effect on different variables such as children's subject knowledge, learning, attitudes, perspectives or behaviors. Sung, Ahn and Black (2017) suggested that the STEM intervention program they utilized using Scratch Jr programming language improved mathematics understanding and programming skills among novice young learners including kindergarten children. Aldemir and Kermani (2017) aimed to design, plan and implement a Science, Technology, Engineering and Math (STEM) model to support Pre-K children's skills and knowledge in STEM and proved that the STEM centered curricula that they used as the instrument of their study improved the number sense and science understandings of preschool children in the study. Another experimental study of Kermani and Aldemir (2015) resulted that content-specific /purposeful and intentional math, science, and technology projects and activities not only contributed to preschool children's science and mathematics learning but also increased their awareness and interest toward STEM subjects. Sullivan and Bers (2017) focused on the technology integration component of STEM education and conducted an experimental research using robots designed specifically for preschool children. The findings of their study reveal that the children in their study group performed highly successful at mastering foundational programming concepts. Master, Cheryan, and Meltzoff (2017) examined the effect of participation to a STEM practice on preschoolers STEM engagement. They suggest that nonacademic social factors, such as group membership can boost young children's STEM motivation. Başaran (2018) reported the impact of STEM activities on preschool children's social work, presentation, teamwork and engineering skills. A recent study by Abanoz (2020) revealed that STEM implementations contribute to the development of scientific process skills of children. 
The results of the literature review set out the findings of various implementations developed with a focus on STEM education from different perspectives. These perspectives can be categorized as the basis and philosophy of the STEM approach, STEM practices for different grade levels, STEM educator training, STEM practice types within and outside the school. Since innovative approaches need to focus on skill development (Çorlu, 2016), it is important to analyze the effectiveness of STEM practices on learning and development of preschool children. Although studies such as examining the attitudes of teachers and preschool children towards STEM studies, determining the perspectives of the STEM approach serve important purposes, experimental studies conducted to demonstrate the effectiveness of STEM practices provide concrete data about the ones found effective in the instructional process. In this context, it is necessary to investigate the results of experimental studies conducted in the preschool period regarding the effectiveness of STEM practices.

The increasing interest in the STEM approach and the research in this field revealed the need for the systematic synthesis of primary studies. Meta-analysis studies that are presented by individual studies are a suitable type of study considered in such research syntheses since they lead to strengthen the validity of similar findings and obtained results, provide external evaluation and support to the statistical significance of the studies with small samples (Abramson, 1994). In addition to this, metaanalysis studies can help to determine inconsistent results obtained from the accumulation of scientific knowledge with an increasing number of studies over time, and to help synthesize old and new findings to guide the policies to be determined in the field (Üstün \& Eryllmaz, 2014). In this context, meta-analysis studies are encouraged in many areas, including educational sciences.

This study aims to investigate the experimental studies using the STEM approach in the preschool period and to evaluate the results with the meta-analysis method. Evaluations of STEM practices may reveal the impact of the implementations and help to make suggestions that will guide future research. In regard to this purpose, the following questions were sought in the study:

What is the effect of STEM practices on the learning and development of preschool children?

Are the measurement results consistent from one study to another?

\section{METHODOLOGY}

\section{Research Design}

To examine the experimental studies using the STEM approach for preschool children, evaluate the effects of their results on the development and learning of preschool children and test the consistency of the study results, the meta-analysis method was used in this study. Meta-analysis is defined as the evaluation of the quantitative data obtained from the studies, which are classified according to defined criteria of the studies carried out on a specific subject (Borenstein, Hedges, Higgins, \& Rothstein, 2009; Dinçer, 2014). Meta-analysis studies, with the capacity to reach comprehensive data as a result of systematic literature review, enable the statistical analysis of the results of the studies on the subject under investigation and to test its accuracy (Hunter \& Schmidt, 1990). Since meta-analysis studies are an effective research synthesis, they are encouraged in many areas including educational sciences (Üstün \& Eryılmaz, 2014). It is thought that the increase in the number of primary studies for the STEM approach raises the need for comprehensive and systematic research synthesis.

Compared to other research syntheses, meta-analysis is stronger since the results are based on the magnitude of impact rather than statistical significance (Borenstein, Hedges, Higgins, \& Rothstein, 2009; Shelby \& Vaske, 2008). For this reason, in this study, it was preferred to use meta-analysis. The studies that are reached as a result of the related literature are selected, coded and analyzed according to the determined criteria. With the analysis, the effect size of the studies included in the research is 
calculated, the heterogeneity test is performed, then the selection of the model, the overall impact calculation and interpretation process are operated.

\section{Sampling}

In this study, journal articles indexed in Web of Science (WoS), Education Resources Information Center (ERIC), National Academic Network and Information Center (ULAKBİM) databases were searched by keywords "STEM education, early childhood, preschool, empirical research, experimental study", both in English and Turkish. The studies carried out between 2010 and 2019 were included in the primary practices. The number of studies reached with the keyword "STEM education" is 5174 in ERIC database, 1562 in WoS database and 56 in ULAKBIMM database. For the keywords used together in different combinations, the number of studies reached is presented in Table 1 by database and keyword distinction.

Table 1.

Number of studies between 2010 and 2019 among the primary studies obtained in WoS, ERIC and ULAKBIM databases

\begin{tabular}{lccc}
\hline & ULAKBIM & ERIC & WoS \\
\hline STEM Education & 56 & 5174 & 1562 \\
STEM Education+Preschool & 2 & 91 & 8 \\
STEM Education+Early Childhood & 0 & 160 & 11 \\
STEM Education+Experimental Study & 4 & 229 & 52 \\
STEM Education+Empirical Research & 0 & 157 & 42 \\
STEM Education+Preschool+Experimental & 1 & 3 & 3 \\
STEM Education+Preschool+Empirical) & 0 & 2 & 2 \\
STEM Education+Early Childhood+Experimental & 0 & 8 & 4 \\
STEM Education+Early Childhood+Empirical & 0 & 4 & 2 \\
\hline
\end{tabular}

\section{Data Collection Tool and Process}

The inclusion criteria of the studies constituting the sample of the research, and the coding and analysis information of the studies that comply with these criteria are shared under separate headings below.

\section{Inclusion criteria}

With the STEM Education keyword, 56 studies were reached in ULAKBIM, 5174 in ERIC and 1562 in WoS databases. By searching the keywords together, the scope was narrowed and the number of studies decreased. The inclusion criteria used in the process are listed below and represented in Figure 1 .

Addresses the practices for STEM education

Targets the preschool period

Focuses on experimental applied work

Having participants as preschool children (not educators)

Being carried out between 2010 and 2019 


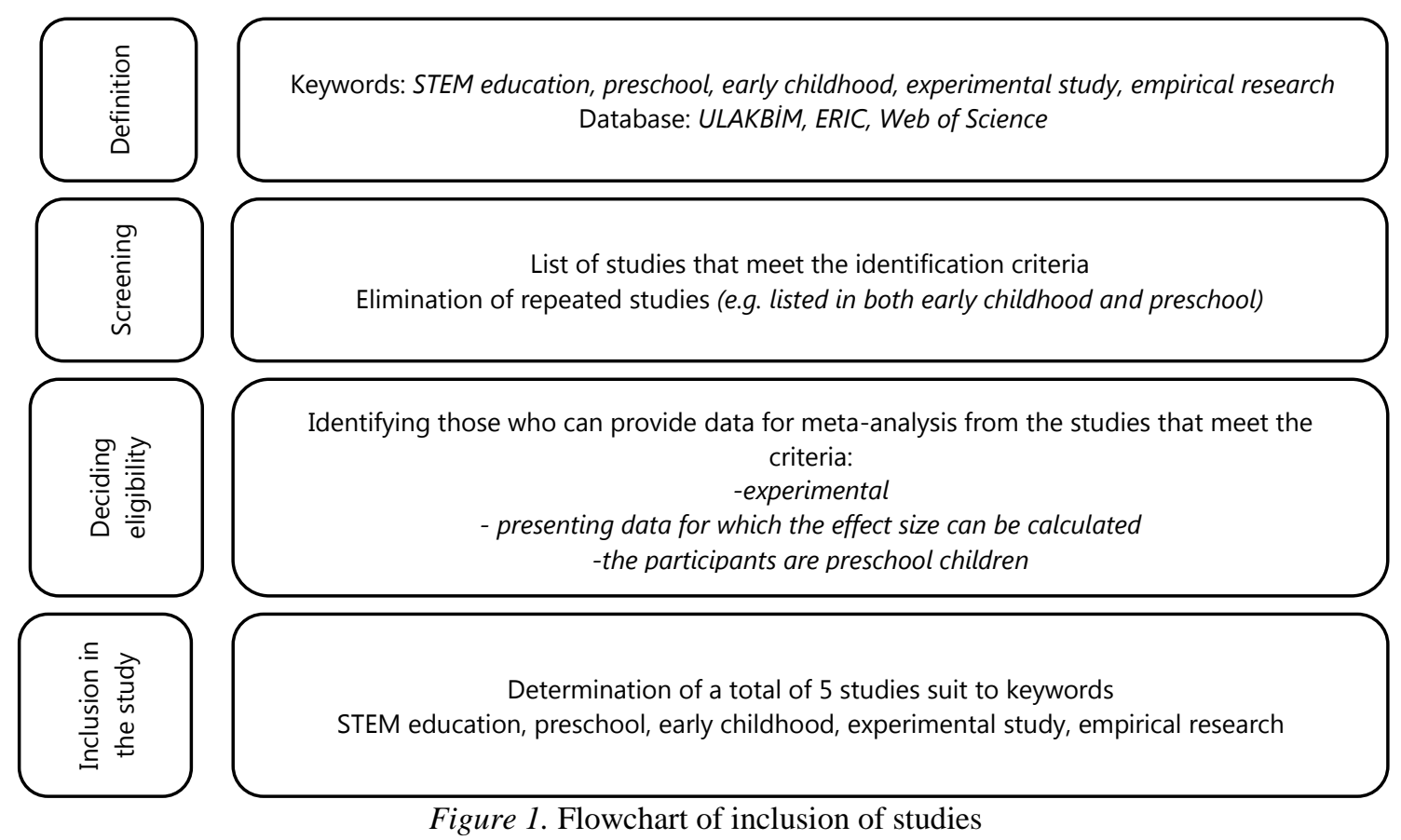

After analyzing the search results one by one, studies that are not suitable for inclusion criteria were excluded. The exclusion of those studies was mainly related to the following reasons: conducted with the qualitative research method, the participants are the grade level other than the preschool period or the participants were educators (preschool teachers or prospective preschool teachers), did not include the quantitative data required for meta-analysis and reached from different databases to avoid duplication.

\section{Coding}

The studies reached for the study were recorded by author and year information. The database, author, year information, title of the study, the method used, participant and measurement tool(s) used for the studies that meet the inclusion criteria are listed in Table 2.

Table 2.

Basic information about the research studies included in the study

\begin{tabular}{|c|c|c|c|c|c|c|}
\hline Database & Author (s) - Year & Title of the Study & Method & Participants & Tool & Duration \\
\hline ERIC & $\begin{array}{l}\text { Kermani \& } \\
\text { Aldemir (2015) }\end{array}$ & $\begin{array}{l}\text { Preparing children for } \\
\text { success: integrating science, } \\
\text { math, and technology in early } \\
\text { childhood classroom }\end{array}$ & $\begin{array}{l}\text { Pre-test post-test } \\
\text { control group } \\
\text { quasi- } \\
\text { experimental } \\
\text { design }\end{array}$ & $\begin{array}{l}58 \text { children in } \\
4 \text { preschool } \\
\text { classes }\end{array}$ & $\begin{array}{l}\text { TEMA-3, teacher } \\
\text { survey, video } \\
\text { recordings, } \\
\text { document analysis }\end{array}$ & 8 weeks \\
\hline ERIC & $\begin{array}{l}\text { Aldemir \& } \\
\text { Kermani (2017) }\end{array}$ & $\begin{array}{l}\text { Integrated STEM curriculum: } \\
\text { improving educational } \\
\text { outcomes for Head Start } \\
\text { children }\end{array}$ & $\begin{array}{l}\text { Pre-test post-test } \\
\text { control group } \\
\text { quasi- } \\
\text { experimental } \\
\text { design }\end{array}$ & $\begin{array}{l}62 \text { children in } \\
4 \text { preschool } \\
\text { classes }\end{array}$ & $\begin{array}{l}\text { TEMA-3, teacher } \\
\text { survey, video } \\
\text { recordings, } \\
\text { document analysis }\end{array}$ & $\begin{array}{l}\text { About } 10 \\
\text { weeks }\end{array}$ \\
\hline ERIC & $\begin{array}{l}\text { Dejonckheere, Wit, } \\
\text { Keere, \& Vervaet } \\
\text { (2016) }\end{array}$ & $\begin{array}{l}\text { Exploring the classroom: } \\
\text { Teaching science in early } \\
\text { childhood }\end{array}$ & $\begin{array}{l}\text { Experimental } \\
\text { study }\end{array}$ & $\begin{array}{l}57 \text { children in } \\
4 \text { preschool } \\
\text { classes }\end{array}$ & $\begin{array}{l}\text { Application with } \\
\text { lighbox }\end{array}$ & 7 weeks \\
\hline ERIC & $\begin{array}{l}\text { Master, Cheryan, } \\
\& \text { Meltzoff (2017) }\end{array}$ & $\begin{array}{l}\text { Social Group Membership } \\
\text { Increases STEM Engagement } \\
\text { Among Preschoolers }\end{array}$ & $\begin{array}{l}\text { Experimental } \\
\text { study-minimal } \\
\text { group design }\end{array}$ & $\begin{array}{l}141 \text { preschool } \\
\text { students }\end{array}$ & $\begin{array}{l}\text { Designed task } \\
\text { scores }\end{array}$ & Unspecified \\
\hline WoS & $\begin{array}{l}\text { Alade, Lauricella, } \\
\text { Beaudoin-Ryan, } \\
\text { \&Wartella (2016) }\end{array}$ & $\begin{array}{l}\text { Measuring with Murray: } \\
\text { Touchscreen technology and } \\
\text { preschoolers' STEM learning }\end{array}$ & $\begin{array}{l}\text { Experimental } \\
\text { study }\end{array}$ & $\begin{array}{l}63 \text { preschool } \\
\text { students }\end{array}$ & $\begin{array}{l}\text { Picture naming } \\
\text { Individual } \\
\text { Development and } \\
\text { Growth Indicator }\end{array}$ & Unspecified \\
\hline
\end{tabular}




\section{Data Analysis}

Comprehensive Meta-Analysis (CMA) software was used to calculate the effect size of the data obtained within the scope of the research. Standardized average differences are taken into account in the calculation of effect sizes. In the meta-analysis, the research included in the study may consist of results obtained from different statistics for the researched problem. This requires standardizing the results before the data is combined.

The standardized mean difference expresses the extent of the intervention effect according to the variability observed in each study (Borenstein et al., 2009; Higgins \& Thomas, 2019). After calculating the effect size, it can be seen that different sources can be utilized in the interpretation of the value obtained. Thalheimer and Cook (2002) suggested that $-0.15-0.15$ range was insignificant, 0.15-0.40 range was small, 0.40- 0.75 range was moderate, $0.75-1.10$ range was wide, 1.10-1.45 range was very wide and above 1.45 the values are an excellent indication of the effect size. Besides, according to Cohen's (1988) criteria, the effect size is small (low) if it is 0.20 and less; medium if it is between 0.20 and 0.80 , it is large if it is 0.80 and above. Heterogeneity testing is needed to determine the model to be used for meta-analysis. Excessive diversity of the studies included in the meta-analysis may cause problems in the interpretation of statistics. Diversity is expected to be reasonable for an accurate and reliable interpretation of results (Çarkungöz \& Ediz, 2009). The heterogeneity test pvalue which is greater than .05 indicates that the distribution is homogeneous and therefore a fixedeffect model can be used. If this value is below .05, a random-effects model should be used (Borenstein et al., 2009). In this study, the heterogeneity test used to determine the model to be used for meta-analysis was performed by the Comprehensive Meta-Analysis (CMA) program and the result was shared in Table 3.

Table 3.

Heterogeneity test results for the studies examining the effect of experimental STEM activities for preschool children

\begin{tabular}{lcccccc}
\hline \multicolumn{1}{c}{ Model } & $\begin{array}{c}\text { \# of Studies } \\
\text { (with subgroups) }\end{array}$ & Effect size & P-value & Q- value & I $^{2-}$ value & $\begin{array}{c}\text { Heterogeneity } \\
\text { P-value }\end{array}$ \\
\hline Fixed Effects Model & 12 & 0.547 & 0.000 & 13.227 & 16.837 & 0.279 \\
Random Effects Model & 12 & 0.556 & 0.000 & & \\
\hline
\end{tabular}

Table 3 shows that the heterogeneity test p-value is greater than .05 . Although this value indicates that the distribution is homogeneous, and fixed effects model is appropriate to use for the analysis; due to the caveat that the model of meta-analysis should not be based on the test for heterogeneity for research accumulating data from a series of studies that were performed independently, randomeffects model is used (Borenstein et al., 2009).

In meta-analysis studies, it is recommended to investigate the effect of publication bias on the average effect size, since the studies included in the research are more likely to be the ones published in statistically significant studies (Borenstein et al., 2009). In this study, Orwin's fail-safe number and funnel graph were used to test publication bias and the findings were presented in Table 4 and Figure 2 .

Table 4.

Orwin's fail-safe number for studies examining the effect of experimental STEM applications for preschool children

\begin{tabular}{lr}
\hline Orwin's fail-safe & \multicolumn{1}{c}{$\mathrm{N}$} \\
\hline Std. diff. in means in observed studies & 0.47046 \\
Criteria for a 'trivial' std. diff. in means & 0.00000 \\
Mean std. diff in means for missing studies & 0.00000 \\
Number of missing studies that would bring p value to >alpha & 134.00000 \\
\hline
\end{tabular}


When the effect size obtained from the analysis was tested, it was determined that 134 non-significant studies were needed for the invalidity of the result obtained. Considering that the number of studies included in the study is 5 and 12 together with its subgroups, this value is approximately 27 (26.8) times the number of studies included, and the total number of studies examined is approximately 11 (11.16) times. This can be considered as proof that the value obtained as a result of the research is independent of publication bias.

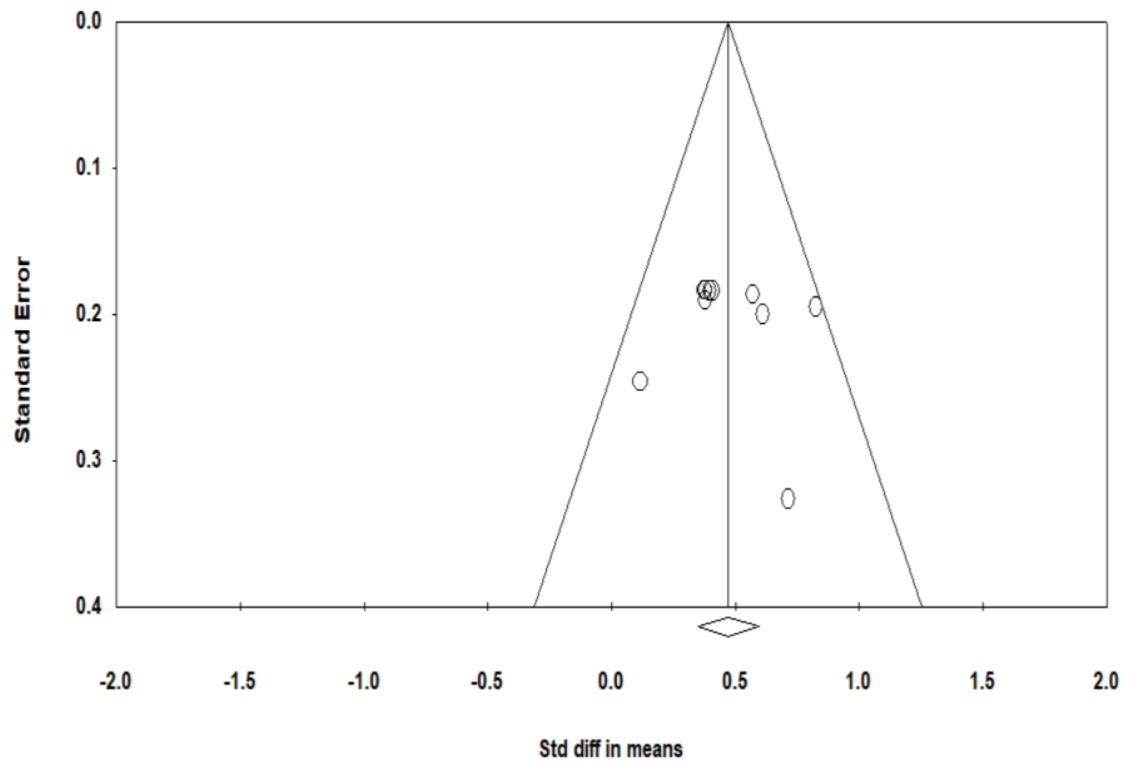

Figure 2. Funnel Plot for the studies examining the effect of experimental STEM applications for preschool children

In Figure 2, when the standard error and standardized mean differences of the studies and subdimensions included in the study are examined, it is seen that all values are in the funnel line. This finding is accepted as an indication that the studies within the scope of the research are not biased (Dinçer, 2014). Figure 3 shows the forest graph for data.

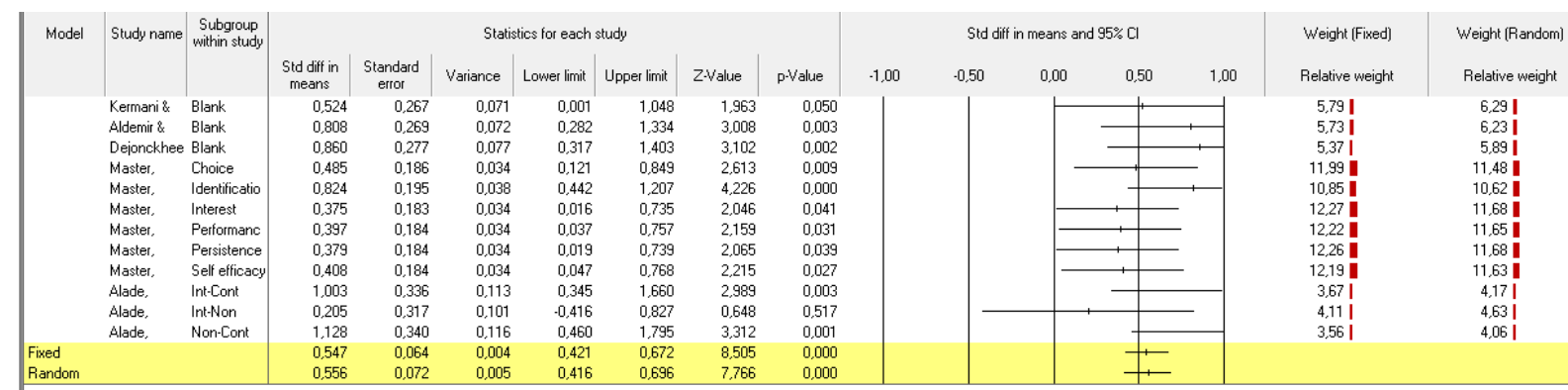

Figure 3. Forest plot showing Std. Diff. in Means with 95\% Confidence Intervals for 5 studies (12 together with sub-groups) investigating the effect of experimental STEM applications for preschool children

Figure 3 shows the studies with sub-groups included in the research as well as the individual effect sizes and confidence intervals. The lines shown in each row in the figure represent the upper and lower limits of the effect sizes within the $95 \%$ confidence interval. When the effect sizes are examined, it is seen that all studies except one subgroup have positive effect. It can be said that STEM applications examined within the scope of the research have an effect in favor of the experimental group.

\section{Validity and Reliability}

For a meta-analysis study to be valid and reliable, the data should be collected and analyzed in the meta-analysis process; the effect model, sample size, recording errors and copies, publication bias 
criteria should be followed, and the studies included in the research should be reviewed by at least two experts (Açıkel, 2009; Akçil, Temel, \& Karaağaoğlu, 2001). To ensure reliability, two researchers involved in this study conducted independent coding and analysis processes for the data, and then came together to agree on their evaluation. In terms of internal validity, it is stated that the diversity of study effects meta-analysis results (Başol \& Johanson, 2009; Kınay 2012). The validity of each study, which was reached within the scope of this study, was examined, and the studies using inappropriate variables or inappropriate methods were excluded from the sample. In the meta-analysis studies, the heterogeneity test contributes to external validity (Wolf, 1988). In this study, heterogeneity test and publication bias were also examined.

\section{FINDINGS}

In this study, which examined the effects of STEM practices for preschool children in their learning and development and the consistency of the results of these studies, 12 results were taken into consideration in 5 major studies and their subgroups to find the answers to the research questions. The effect size, variance, standard error, p-value, confidence interval and study interval values of each study together with the subgroups are presented in Table 5.

Table 5.

Individual meta-analysis results of research and sub-groups for the studies examining the effect of experimental STEM applications for preschool period

\begin{tabular}{|c|c|c|c|c|c|c|c|c|c|}
\hline \multirow[b]{2}{*}{ Model } & \multirow[b]{2}{*}{ Study } & \multirow[b]{2}{*}{$\begin{array}{l}\text { Effect } \\
\text { size }\end{array}$} & \multirow[b]{2}{*}{ Variance } & \multirow[b]{2}{*}{$\begin{array}{l}\text { Std. } \\
\text { Err. }\end{array}$} & \multirow[b]{2}{*}{$\begin{array}{c}\mathrm{P} \\
\text { value }\end{array}$} & \multicolumn{2}{|c|}{$\mathrm{CI}$} & \multicolumn{2}{|c|}{ SI } \\
\hline & & & & & & $\begin{array}{l}\text { Lower } \\
\text { limit }\end{array}$ & $\begin{array}{l}\text { Upper } \\
\text { limit }\end{array}$ & $\begin{array}{c}\text { Fixed } \\
\text { Effects } \\
\text { Model }\end{array}$ & $\begin{array}{c}\text { Random } \\
\text { Effects } \\
\text { Model }\end{array}$ \\
\hline & $\begin{array}{l}\text { Kermani \& Aldemir } \\
\text { (2015) }\end{array}$ & 0.524 & 0.071 & 0.267 & 0.050 & 0.001 & 1.048 & 5.79 & 6.29 \\
\hline & $\begin{array}{l}\text { Aldemir \& Kermani } \\
\text { (2017) }\end{array}$ & 0.808 & 0.072 & 0.269 & 0.003 & 0.282 & 1.334 & 5.73 & 6.23 \\
\hline & \multirow[t]{3}{*}{$\begin{array}{l}\text { Dejonckheere, Wit, } \\
\text { Keere \& Vervaet (2016) }\end{array}$} & 0.860 & 0.077 & 0.277 & 0.002 & 0.317 & 1.403 & 5.37 & 5.89 \\
\hline & & 0.485 & 0.034 & 0.186 & 0.009 & 0.121 & 0.849 & 11.99 & 11.48 \\
\hline & & 0.824 & 0.038 & 0.195 & 0.000 & 0.442 & 1.207 & 10.85 & 10.62 \\
\hline & Master, Cheryan \& & 0.375 & 0.034 & 0.183 & 0.041 & 0.016 & 0.735 & 12.27 & 11.68 \\
\hline & \multirow{3}{*}{ Meltzoff (2017) } & 0.397 & 0.034 & 0.184 & 0.031 & 0.037 & 0.757 & 12.22 & 11.65 \\
\hline & & 0.379 & 0.034 & 0.184 & 0.039 & 0.019 & 0.739 & 12.26 & 11.68 \\
\hline & & 0.408 & 0.034 & 0.184 & 0.027 & 0.047 & 0.768 & 12.19 & 11.63 \\
\hline & Alade, Lauricella, & 1.003 & 0.113 & 0.336 & 0.003 & 0.345 & 1.660 & 3.67 & 4.17 \\
\hline & Beaudoin-Ryan & 0.205 & 0.101 & 0.317 & 0.517 & -0.416 & 0.827 & 4.11 & 4.63 \\
\hline & \&Wartella (2016) & 1.128 & 0.116 & 0.340 & 0.001 & 0.460 & 1.795 & 3.56 & 4.06 \\
\hline Fixed $\mathrm{B}$ & fect Model & 0.547 & 0.004 & 0.064 & 0.000 & 0.421 & 0.672 & & \\
\hline Randor & Effects Model & 0.556 & 0.005 & 0.072 & 0.000 & 0.416 & 0.696 & & \\
\hline
\end{tabular}

When Table 5 is examined, it is seen that the effect sizes for the 12 studies with sub-groups vary between $0.205-1.128$. The total effect size of the study is presented in the last two rows of the table specified with Fixed Effect Model and Random Effects Model. Given the details grounded above, the Random Effects Model value was evaluated. For this model, it is seen in the table that the effect size is 0.556 , the variance is 0.005 and standard error is 0.072 in the confidence interval of $0.416-0.696$. Considering the scale of Thalheimer and Cook (2002), it can be said that the studies within the scope of this research have a moderate effect size. 


\section{DISCUSSION}

This study examined the effects of STEM practices for preschool children in their learning and development. 12 results accumulated from 5 different experimental STEM studies that meet the inclusion criteria of the study were analyzed and the data of 381 participants were evaluated. Of these five studies, two of them (Aldemir \& Kermani, 2017; Kermani \& Aldemir, 2015) were reporting the effects of integrated STEM practices on mathematics skills of preschool children, one of them (Dejonckheere et al., 2016) examined the effects of STEM education on the achievement of science concepts and scientific reasoning, one of them (Master et al., 2017) examined the effect of group work on the level of participation in STEM applications, and the last one (Alade et al., 2016) examined the impact of touch screen technology on STEM learning.

The studies included in the investigation were determined to have a homogeneous structure but as explained in the data analysis title under method section random-effects model was used. According to the random effects model, the overall effect size value of the studies was calculated as 0.556 . This value shows that the average effect size of the studies included in the study was moderate according to the scale proposed by Thalheimer and Cook (2002). A positive mean effect size value indicates that the effect of the process is in favor of the experimental group. Therefore, it can be said that STEM practices for preschool children have positive effects on their learning and development. This result is consistent with the results obtained by Başaran (2018) and Abanoz (2020) in their studies.

When the individual effect sizes of the studies included in the study are examined, it is seen that there is only one result that corresponds to a range different from the average effect size. This study by Alade et al. (2016) examines the effect of touch-screen devices on preschool children's learning science-math concepts. Meta-analysis method, neglects the individual outcomes that are in opposite directions. In this study, the opposite direction value can be interpreted as a sign that the sample of the research was chosen impartially and the research was conducted with realistic data regardless of neglecting any outcome (Borenstein et al., 2009). In the other four studies included in the study (Aldemir \& Kermani, 2017; Dejonckheere et al., 2016; Kermani \& Aldemir 2015; Master et al., 2017), the individual effect size of each study, in which the effect of the method or the material of the study on the development or learning of preschool children on STEM subjects is investigated, was found to be close to the overall effect size, and this effect size showed moderate level. When these results are reviewed by considering the research questions, it can be said that the methods and materials used in the studies have the potential to contribute positively to the development and learning of preschool children on STEM subjects and the measurement results are consistent. When the results are evaluated in terms of research bias, it was found that there was no publication bias, since 134 non-significant studies (27 times the number of studies included) were needed for the invalidity of the research result.

The findings obtained from this study were attempted to be compared with the related studies in the literature but no meta-analysis study examining the effects of experimental STEM practices on the development and learning of preschool children was found. In a recent work of a content analysis on STEM research in Turkey by Aydın-Günbatar and Tabar (2019) 67 articles were examined and it is reported that $50 \%$ of the study was qualitative study, with $40 \%$ of the participants are students and of $38 \%$ are teachers. The fact that half of the 67 studies are qualitative research is in line with the low number of experimental studies (5 studies) conducted with preschool children that are reached in this research. In Kanadli's (2019) meta-summary study, the frequency of the effect sizes was calculated for 22 research reports and 31 expressions were conceptualized under various themes, but there is no focus of experimental study effect on the development and learning of preschool children. Saraç (2018) in a meta-analysis study, which examined the effects of STEM practices on students' learning, evaluated 23 articles addressing primary, secondary and tertiary education published between 20102017 and calculated the effect sizes for students' academic achievement, scientific process skills and attitudes towards STEM disciplines. The study reported a moderate effect by calculating 0.442 for academic success and 0.620 for attitude towards STEM disciplines and a wide effect by calculating 0,820 for scientific process skills. Different from Saraç's (2018) research, this study addressed the 
preschool education and the effect of experimental studies on development and learning of preschool children. The results of this study are in compliance with the results of Saraç (2018) for academic success and attitude towards STEM subjects which can explain the positive effect of interventions in this study. Belland, Walker, Kim, and Lefler's (2017) meta-analysis study examines the effect of computer-based scaffolding assistance on students' finding solutions to complex problems. They reported that computer-based scaffolding assistance has a lasting positive effect on students' learning $(\bar{g}=0.46)$. The fact that 11 of the computed effect sizes resulted with positive value within the scope of this study confirms the findings of Belland et.al. (2017).

This study has some limitations. The first one is the number of studies included in the study. In metaanalysis studies, the high number of individual studies to be included will increase the sensitivity and power of the study (Üstün \& Eryllmaz, 2014). In this meta-analysis, 12 results from five studies meeting the inclusion criteria could be considered. The inclusion criteria of the study also constitute other limitations of the study. Although Valentine, Pigott, and Rothstein (2010) argue that metaanalysis can be performed even with two studies, it is considered when more studies are conducted and analyzed meta-analysis may yield different results. Other limitations are the constraint of the date of publications which is limited with the last 10 years, the elimination of qualitative studies and quantitative studies on perception and views, the constraint of study method which is limited with experimental studies that focus on the effects of STEM activities and the constraint of the participants which is limited with preschool children. The number of few studies reached within the scope of this study that meet the inclusion criteria indicates that more experimental STEM studies are needed in the preschool field and that more rigorous reporting is required. When the studies within the scope of the investigation are analyzed in terms of sample groups, it is seen that the number of participants is close to each other, 57, 58, 60, 62 in 4 studies and 141 in one study. It is thought that the studies conducted with larger samples will increase the validity and reliability of the results and contribute to the results of meta-analysis. As a result of this meta-analysis, it is recommended to make long term implications with larger sample groups and to examine their results.

\section{CONCLUSION AND RECOMMENDATION}

The fact that there is an increasing number of studies on the STEM approach which is adopted in our country as in the developing countries, brings with it the need to evaluate the results of these studies in a holistic and comparative perspective. This study aimed to investigate the effects of STEM practices on preschool children's learning and development and the consistency of the results of these studies. In this study, experimental studies using the STEM approach for preschool children were examined and the results were evaluated with the meta-analysis method.

The research was conducted in the databases of Web of Science (WoS), Education Resources Information Center (ERIC), National Academic Network and Information Center (ULAKBIM). The literature search was performed with the keywords "STEM education, early childhood, preschool, empirical research, experimental study" both in Turkish and English languages. The results were constrained with the criteria (1) the study is on STEM education, (2) the intervention is targeting the pre-school period, (3) the study is experimental research (4) the participants are preschool children and (5) the study was conducted between 2010 and 2019. These studies investigated the effects of designed STEM model, project, curricula or activity on preschool children's learning and development in respect to different focus on learning or development (e.g. achievement of math concept measurement or development in scientific reasoning). The instruments used to measure the level of children's learning or developments were different and the focus on each learning or development also differed from one study to another. Three of five studies investigated the effect on preschool children's mathematics and science achievement while one study investigated scientific reasoning and the last one focused on the effect of social group membership on STEM subject learning of children. 
Developing the science and mathematics literacy of individuals which is one of the main objectives of STEM approach; conducting investigations that address interpreting and adapting daily life experiences with science, mathematics and engineering skills through holistic perspective; examining the impact of the studies on learning and development and evaluating their results with meta-analysis can contribute to reveal the effectiveness of STEM practices. Based on the findings of this study it may be suggested that preschool teachers can be encouraged to design and implement STEM practices in their class. For the prospective studies; the research that was reached but excluded from the scope of this study because they did not meet the research criteria can be examined to point out their findings; to expand the meta-analysis results of the preschool studies that are considered as focus in this study with content analysis; to evaluate the findings of the study with the same keywords for other grade levels such as primary, secondary and high school. Furthermore the keywords can be extended with the synonyms or Boolean Operations between keywords and statistical techniques can be included.

\section{REFERENCES}

Abanoz, T. (2020). Stem yaklaşımına uygun fen etkinliklerinin okul öncesi dönem çocuklarının bilimsel süreç becerilerine etkisinin incelenmesi [The examination of the impact of science education activities based on stem approach on preschool term children's science process skills]. (Unpublished doctoral dissertation). Gazi University, Ankara.

Abramson, J.H. (1994). Making sense of data. New York: Oxford University Press.

Açıkel, C. (2009). Meta analiz ve kanıta dayalı tıptaki yeri [Meta-analysis and its place in evidence-based medicine]. Klinik Psikofarmoloji Bülteni, 19(2), 164-172.

Akçil Temel, M., \& Karaağaoğlu, E. (2001). Tipta meta-analizi [Meta-analysis in medicine]. Hacettepe Medical Journal, 32(2), 184-190.

Akgündüz, D., Aydeniz, M., Çakmakçı, G., Çavaş, B., Çorlu, M., Öner, T., \& Özdemir, S. (2015). STEM eğitimi Türkiye raporu: Günümüz modası mı yoksa gereksinim mi? [Turkey STEM education report: Is it need or contemporary fashion?] İstanbul Aydın University STEM Center, İstanbul.

Alade, F., Lauricella, A.R., Beaudoin-Ryan, L., \& Wartella, E. (2016). Measuring with Murray: Touchscreen technology and preschoolers' STEM learning. Computers in Human Behavior, 62, 433-441. DOI: 10.1016/j.chb.2016.03.080

Aldemir, J., \& Kermani, H. (2017). Integrated STEM curriculum: improving educational outcomes for Head Start children. Early Child Development and Care, 187(11), 1694-1706. DOI: 10.1080/03004430.2016.1185102

Aral, N., Baran, G., Bulut, Ş., \& Çimen, S. (2000). Çocuk gelişimi I [Child Development I]. İstanbul: Ya-Pa Yayıncılık.

Aşık, G., Doğança Küçük, Z., Helvacı, B., \& Çorlu, M. S. (2017). Integrated teaching project: A sustainable approach to teacher education. Turkish Journal of Education, 6(4), 200-215. DOI: 10.19128/turje.332731

Aydın-Günbatar, S.A., \& Tabar, V. (2019). Türkiye'de gerçekleştirilen STEM araştırmalarının içerik analizi [Content analysis of the STEM research in Turkey]. YYÜ Eğitim Fakültesi Dergisi, 16(1), 1054-1083. DOI: $10.23891 /$ efdyyu.2019.153

Başaran, M. (2018). Okul öncesi eğitimde STEM yaklaşımının uygulanabilirliği (eylem araştırması) [The applicability of STEM approach in preschool education (action research)] (Unpublished doctoral dissertation). Gaziantep University, Gaziantep.

Başol, G., \& Johanson, G. (2009). Effectiveness of frequent testing over achievement: A meta-analysis study. International Journal of Human Sciences, 6(2), 99-121.

Belland, B.R., Walker, A.E., Kim, N.J., \& Lefler, M. (2017). Synthesizing results from empirical research on computer-based scaffolding in STEM Education: A Meta-analysis. Review of Educational Research, 87(2), 309-344. DOI: 10.3102/0034654316670999

Borenstein, M., Hedges, L. V., Higgins, J. P. T., \& Rothstein, H. R. (2009). Introduction to meta- analysis. West Sussex-UK: John Wiley \& Sons Ltd.

Cohen, J. (1988). Statistical Power analysis for the behavioral sciences. Hillsdale, NJ: Lawrance Earlbaum Associates.

Çarkungöz, E., \& Ediz, B. (2009). Meta analizi (Meta-analysis]. Uludag University Journal of Faculty Veterinary Medicine, 28(1), 33-37.

Çorlu, S. (2016). Bütünleşik öğretmenlik projesi [STEM: Integrated teaching project], FeTeMM Öğretmen Bülteni [STEM Teacher Bulletin], 1(1), 1-15. 
Dejonckheere, P.J.N., Wit, N.D., Keere, K.V., \& Vervaet, S. (2016). Exploring the classroom: Teaching science in early childhood. International Electronic Journal of Elementary Education, 8(4), 537-558.

Dinçer, S. (2014). Eğitim bilimlerinde uygulamalı meta-analiz [Applied meta-analysis in educational sciences]. Ankara: Pegem Akademi Yayıncılık.

Gropen, J., Clark-Chiarelli, N., Hoisington, C., \& Ehrlich, S. B. (2011). The importance of executive function in early science education. Child Development Perspectives, 5(4), 298-304. DOI: 10.1111/j.17508606.2011.00201.x

Higgins JPT, Thomas J, Chandler J, Cumpston M, Li T, Page MJ, Welch VA (editors). Cochrane Handbook for Systematic Reviews of Interventions. $2^{\text {nd }}$ Edition. Chichester (UK): John Wiley \& Sons, 2019.

Hunter, J. E., \& Schmidt, F. L. (1990). Methods of meta-analysis: Correcting error and bias in research findings. Thousand Oaks, CA, US: Sage Publications, Inc.

Kanadli, S. (2019). A meta-summary of qualitative findings about STEM education. International Journal of Instruction, 12(1), 959-976. DOI:10.29333/iji.2019.12162a

Katz, L. G. (2010). STEM in early years. Paper presented at the SEED (STEM in Early Education and Development) Conference, University of Northern Iowa, Cedar Falls, Iowa, USA. Retrieved from http://ecrp.uiuc.edu/beyond/seed/katz.htm

Kermani, H. \& Aldemir, J. (2015). Preparing children for success: integrating science, math, and technology in early childhood classroom, Early Child Development and Care, 185(9), 1504-1527. DOI: $10.1080 / 03004430.2015 .1007371$

Kınay, E. (2012). Universite sınavı yordama geçerliği çalışmalarının meta-analizi [A meta-analysis on the predictive validity studies of university entrance examinations]. (Unpublished master's thesis). Ankara University, Ankara.

Master, A., Cheryan, S., \& Meltzoff, A.N. (2017). Social group membership increases STEM engagement among preschoolers, Developmental Psychology, 53(2), 201-209. DOI: 10.1037/dev0000195

Moomaw, S. (2013). Teaching STEM in the early years. USA: Redleaf Press

Saraç, H. (2018). The effect of science, technology, engineering and mathematics-STEM educational practices on students' learning outcomes: A meta-analysis study. The Turkish Online Journal of Educational Technology, 17(2), 125-142.

Shelby, L.B., \& Vaske, J.J. (2008). Understanding meta-analysis: A review of the methodological literature. Leisure Sciences, 30, 96-110. DOI: 10.1080/01490400701881366

Sullivan, A., \& Bers, M.U. (2017). Dancing robots: integrating art, music, and robotics in Singapore's early childhood centers. International Journal of Technology and Design Education, 28(1). DOI: 10.1007/s10798-017-9397-0

Sung, W., Ahn, J. \& Black J.B. (2017). Introducing computational thinking to young learners: Practicing computational perspectives through embodiment in mathematics education. Technology, Knowledge and Learning, 22, 443-463. DOI: 10.1007/s10758-017-9328-x

Thalheimer, W., \& Cook, S. (2002). How to calculate effect sizes from published research articles: A simplified methodology. https://www.bwgriffin.com/gsu/courses/edur9131/content/Effect_Sizes_pdf5.pdf

Tuğrul, B. (2002). Erken çocukluk döneminde öğrenmeyi ve öğretimi kolaylaştıran özellikler [Aspects that contribute to teaching and learning in the early childhood years]. Hacettepe Üniversitesi Eğitim Fakültesi Dergisi, 22,142-147.

Üstün, U. \& Eryılmaz, A. (2014). A Research Methodology to Conduct Effective Research Syntheses: MetaAnalysis. Education and Science, 39(174), 1-32. DOI: 10.15390/EB.2014.3379

Valentine, J., Pigott, T., \& Rothstein, H. (2010). How Many Studies Do You Need? A Primer on Statistical Power for Meta-Analysis. Journal of Educational and Behavioral Statistics, 35, 215-247. DOI: 10.3102/1076998609346961

Wolf, F.M. (1988). Meta-Analysis Quantitative Methods for Research Synthesis. California: Sage Publications. 


\section{TÜRKÇE GENIŞLETILMIŞ ÖZET}

Bireylerin erken yaşlardan itibaren çevrelerinde yaşananlara duyarlı olup, gözlemledikleri sorunlara çözüm ya da iyileştirme önerileri getirmeleri, olayları bütüncül bir bakış açısıyla ve yenilikçi bir yaklaşımla değerlendirmeleri gelişmiş eğitim sistemlerinin öncelikleri arasında yer almaktadır. 21. yüzyıl öğrenci profilini oluşturmak adına disiplinleri bir araya getiren çeşitli yaklaşımlar, modeller ve uygulamalara dönük arayışlar devam etmektedir. Bu arayışın en somut örneklerinden biri de disiplinler arası bir yaklaşım olan STEM (Science-Technology-Engineering-Mathematics) çalışmalarıdır. STEM yaklaşımı, bütünleşik yapısı ile öğretim yaklaşımlarının hedeflediği ve ihtiyaç duyulan çok disiplinli yapıyı karşılarken aynı zamanda öğrencilerin öğrenmeleri ile ilgili çeşitli firsatlar elde etmelerine zemin hazırlamaktadır.

STEM çalışmaları pek çok öğrenim kademesinde uygulama alanı bulmaktadır. Bu alanlardan biri de okul öncesi eğitim kademesidir. Henüz okuma, yazma ile ilgili yeterliliğe sahip olmayan çocukların yer aldığı bir dönem olan okul öncesi dönemde öğrenme; çocuğa bilgi yüklemek yerine onların farklı açılardan gelişimlerini bütüncül olarak destekleyecek yaşamın içinde, çocuğun yakın çevresinde aşina olduğu durumları içermektedir. Bu durumları öğretim ile ilişkilendirmede güçlü bir yol olarak STEM uygulamalarından yararlanılabilir. Bir başka deyişle, STEM eğitimi, okul öncesi çocuklarının temel becerilerini geliştirmede önemli bir araç olarak değerlendirilebilir. STEM uygulamalarının etkisini ortaya koyabilmek için diğer öğrenim kademelerinde olduğu gibi okul öncesi dönemde de çocukların temel becerileri, öğrenme ve gelişimlerine yönelik çalışmaların yapılması önemlidir. Bununla birlikte, STEM yaklaşımına yönelik bireysel çalışmaların tek tek ortaya koyduğu sonuçların toplamdaki etkisinin ortaya konulması ve zaman içerisinde çalışma sayısının artması ile elde edilen eski ve yeni bulguların sentezlenmesi meta-analiz çalışmaları ile mümkün olabilir.

$\mathrm{Bu}$ çalışmanın amacı okul öncesi dönemde STEM yaklaşımının kullanıldığı deneysel araştırmaların incelenerek sonuçlarının meta-analiz yöntemiyle değerlendirilmesidir. Bu amaç doğrultusunda çalışmada (1) STEM yaklaşımı temelli uygulamaların okul öncesi dönem çocuğunun öğrenmesine ve gelişimine etkisi nasıldır? (2) Ölçme sonuçları bir çalışmadan diğer bir çalışmaya göre tutarlı mıdır? sorularına yanıt aranmıştır. Bu çalışmada meta-analiz yönteminden yararlanılmıştır. Araştırmaya Web of Science (WoS), Education Resources Information Center (ERIC), Ulusal Akademik A $\breve{g}$ ve Bilgi Merkezi (ULAKBİM) veri tabanlarında konu alanında İngilizce olarak "STEM education, early childhood, preschool, empirical research, experimental study", Türkçe olarak "STEM eğitimi, erken çocukluk, okul öncesi, ampirik araştırma, deneysel çalışma" kelimeleri ile arama yapıldı̆̆ında elde edilen birincil uygulamalardan 2010 ve 2019 yılları arasında gerçekleştirilen çalışmalar dahil edilmiştir. Süreçte kullanılan dahil edilme ölçütleri (1) STEM eğitimine yönelik çalışma olması, (2) Okul öncesi döneme yönelik olması, (3) Uygulamalı alan çalışması olması, (4) Katılımcılarının erken çocukluk döneminde bulunması ve (5) Çalışmanın 2010 ve 2019 yılları arasında gerçekleştirilmiş olmasidır.

Araştırma kapsamında elde edilen verilerin etki büyüklüğü hesaplaması için "Comprehensive MetaAnalysis (CMA)" yazılımından yararlanılmıştır. Etki değerleri hesaplamasında standardize edilmiş ortalama farklar dikkate alınmıştır. Genel etki analiz sonuçları için heterojenlik testi yapılarak uygun modelin seçimine karar verilmiş ve bulgular değerlendirilmiştir. Güvenirliğin sağlanması amacıyla, bu çalışmada yer alan iki araştırmacı verilerin kodlanması ve analizinde bağımsız değerlendirmelerini gerçekleştirmiş, sonrasında bir araya gelerek değerlendirmeleri konusunda fikir birliğine varmıştır. Araştırma kapsamında ulaşılan her bir çalışmanın geçerliğine bakılmış, uygun olmayan değişkenlerin kullanıldığ ya da uygun olmayan yöntemlerle analiz edilmiş çalışmalar örneklemden çıkarılmış ve araştırma kapsamında ulaşılan beş çalışmanın yayın yanlılığına bakılmıştır.

Okul öncesi dönem çocuklarına yönelik olarak uygulanan STEM etkinliklerinin çocukların öğrenmelerine ve gelişimlerine nasıl bir etki oluşturduğunu ve bu etkinlikleri ele alan çalışmaların 
ölçme sonuçlarının tutarlılığını inceleyen araştırma kapsamında dahil edilme ölçütlerine uyan 5 çalışmaya ulaşılmış, ulaşılan beş çalışmanın alt grupları dikkate alındığında bulgular 12 çalışma üzerinden araştırma sorusuna cevap bulmak üzere değerlendirilmiştir. Meta-analiz için kullanılacak modelin belirlenmesi için heterojenlik testi uygulanmış ve $p$ değeri 0,05 'ten büyük bulunmuştur $(\mathrm{p}=0,279)$. Bu değerin önerdiği sabit etki modeli olmasına rağmen; meta-analiz modelinin, bağımsız olarak gerçekleştirilen bir dizi çalışmadan veri toplayan araştırma için heterojenlik testine dayanmaması gerektiği uyarısı nedeniyle, rastgele etki modelinden yararlanılmıştır (Borenstein, Hedges, Higgins \& Rothstein, 2009). Araştırmada alt boyutlarıyla birlikte toplam 12 çalışma için etki değeri büyüklüklerinin $0,205-1,128$ aralığında değiştiği görülmektedir. Araştırmaya ait toplam etki değeri 0,416-0,696 güven aralığında 0,556, varyans 0,005 ve standart hata 0,072 olarak hesaplanmıştır. Bu bulgu ışığında çalışma kapsamındaki araştırmaların orta düzeyde bir etki değerine sahip olduğu söylenebilir.

$\mathrm{Bu}$ çalışmada yayın yanlılığını test etmek için Orwin'in hata koruma sayısı ve huni grafiğinden yararlanılmıştır. Analiz sonucunda ulaşılan etki büyüklüğünün ne kadar güçlü olduğu test edildiğinde, elde edilen sonucun geçersizliği için, manidar olmayan 134 çalışmaya ihtiyaç duyulduğu belirlenmiştir. Bu değer çalışmaya dahil edilen çalışma sayısının 5, alt gruplarıyla birlikte 12 olduğu göz önüne alındığında araştırmaya dahil edilen çalışma sayısının yaklaşık 27 katı $(26,8)$, toplam incelenen araştırma sayısının ise yaklaşık 11(11,16) katıdır ki araştırma sonucunda elde edilen değerin gücünün yayın yanlılığından bağımsız olduğunun kanıtı olarak değerlendirilebilir. Araştırmaya dahil edilen çalışmaların alt boyutları ile birlikte bireysel etki değeri \%95 güven aralığında incelendiğinde bir alt boyut hariç tüm çalışmaların pozitif etkiye sahip olduğu görülmektedir.

Okul öncesi dönem çocuklarına yönelik olarak uygulanan STEM etkinliklerinin çocukların öğrenmelerine ve gelişimlerine nasıl bir etki oluşturduğunu ve bu etkinlikleri ele alan çalışmaların ölçme sonuçlarının tutarlılığını incelemeyi amaçlayan bu çalışmada ortalama etki büyüklüğü değerinin pozitif çıkması, işlem etkisinin deney grubu lehine olduğunu göstermektedir. Bu nedenle okul öncesi dönem çocuklarına yönelik olarak gerçekleştirilmiş uygulamalı STEM çalışmalarının çocukların öğrenme ve gelişimleri üzerinde olumlu etki oluşturduğu söylenebilir. Bununla birlikte, bu çalışmanın sınırlılı̆̆ı, araştırmaya dahil edilen çalışma sayısıdır. Bu durum okul öncesi alanında daha fazla sayıda STEM konulu deneysel çalışmaya ihtiyaç olduğunu göstermektedir. İleriye dönük çalışmalar için, bu araştırmada ulaşılan ancak araştırma ölçütlerini sağlamadığı için kapsam dışı bırakılan çalışmaların incelenerek bu çalışmada odak olarak ele alınan okul öncesi dönemi çalışmalarının meta analiz sonuçlarının içerik analizi ile desteklenmesi önerilebilir. Ayrıca, okul öncesi dönemi dışında ilköğretim, ortaokul, lise gibi diğer sınıf seviyeleri için aynı anahtar kelimeler ile gerçekleştirilecek çalışma bulgularının değerlendirilmesi önerilebilir. Bunun dışında, anahtar kelimeler eşanlamlıları ile genişletilip anahtar kelimeler arasında Boolean İşlemleri ve istatistiksel teknikler dahil edilebilir. 